14-3-3n since HIGH 14-3-3n were then present in 32/162 (19.7\%) SJC $=0$ patients; 22/108 (20.4\%) SJC+TJC=0 and 13/56 (23.2\%) Boolean.

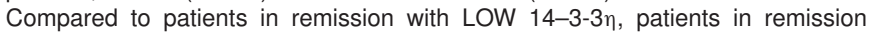

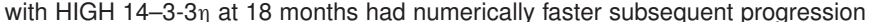
with all definitions. For example, in patients with Boolean remission, mean (SD) erosion progression over 42 months was $7.2 \pm 13.1$ vs $1.5 \pm 3.3$ and mean (SD) progression of Total score $9.2 \pm 14.5$ vs $2.8 \pm 4.4$ units (Figure).

However, due to low numbers and limited power, differences in progression were statistically significant only for the less strict definitions of remission and only over the following year: Erosions $(\mathrm{SJC}=0, \mathrm{p}=0.0042$, $\mathrm{SJC}+\mathrm{TJC}=0, \mathrm{p}=0.0236)$, Total score $(\mathrm{SJC}=0, \mathrm{p}=0.0146$; with a trend for $\mathrm{SJC}+\mathrm{TJC}=0, \mathrm{p}=0.077$ ).

None of the comparisons over 42 months or of those involving Boolean reached significance.

Figure. Progression of Erosion Sharp/van der Heijde score in patient s in Boolean remission at 18 months.

A. $14-3-3 \eta<0.50 \mathrm{ng} / \mathrm{ml}$ at 18 months. B. $14-3-3 \eta \geq 0.50 \mathrm{ng} / \mathrm{ml}$ at 18 months.

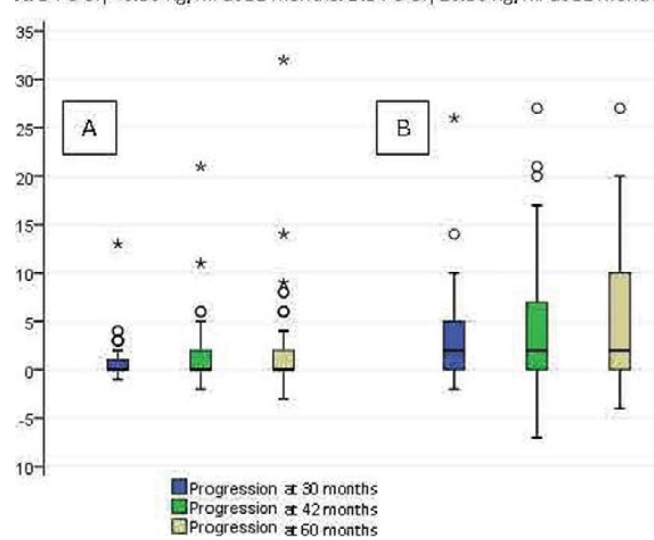

Conclusions: The persistence of $14-3-3 \eta$ levels $\geq 0.50 \mathrm{ng} / \mathrm{ml}$ appears to be associated with a lower probability of reaching remission in polyarthritis patients. $14-3-3 \eta$ levels $>0.50 \mathrm{ng} / \mathrm{ml}$ in patients in clinical remission appear to be associated with more rapid radiographic (especially erosive) progression over the following year. A larger study is required to validate these findings, especially with the most stringent criterion of Boolean remission.

Disclosure of Interest: N. Carrier: None declared, M.-P. Garant: None declared, A. Marotta Employee of: Augurex Life Sciences Corp., A. De Brum Fernandes Grant/research support from: AJdBF is part of the Centre de Recherche Clinique from the CHUS, which received a team grant from the Fonds de Recherche en Santé-Québec, P. Liang: None declared, A. Masetto: None declared, Y. Gui Employee of: Augurex Life Sciences Corp., J. Savill Employee of: Augurex Life Sciences Corp., S. Michienzi Employee of: Augurex Life Sciences Corp., W. Maksymowych Consultant for: Augurex Life Sciences Corp., G. Boire Grant/research support from: GB is part of the Centre de Recherche Clinique from the CHUS, which received a team grant from the FRSQ. GB is the recipient of CIHR grant MOP-110959. Since 2007, the Sherbrooke EUPA cohort has also received financial support from the Canadian ArTritis CoHort (CATCH), a study designed and implemented by investigators and financially supported via unrestricted research grants initially by Amgen Canada Inc

DOI: 10.1136/annrheumdis-2017-eular.4085

\section{FRI0048 THE ANTI-CD20 ANTIBODY RITUXIMAB REDUCES THE INFLAMMATORY AND PROTHROMBOTIC PROFILE OF LEUKOCYTES FROM RHEUMATOID ARTHRITIS PATIENTS AND MODULATES THE ACTIVITY OF ENDOTHELIAL CELLS}

I. Cecchi ${ }^{1}$, C. Perez-Sanchez ${ }^{2}$, P. Ruiz-Limon ${ }^{2}$, I. Arias de la Rosa ${ }^{2}$, M.C. Abalos-Aguilera ${ }^{2}$, Y. Jimenez-Gomez ${ }^{2}$, R. Ortega ${ }^{2}$, E. Collantes-Estevez ${ }^{2}$, A. Escudero ${ }^{2}$, N. Barbarroja ${ }^{2}$, S. Sciascia ${ }^{1}$, C. Lopez-Pedrera ${ }^{2}$. ${ }^{1}$ Department of Clinical and Biological Sciences, Center of Research of Immunopathology and Rare Diseases - Coordinating Center of Piemonte and Valle d'Aosta Network for Rare Diseases, Turin, Italy; ${ }^{2}$ GC-5/Rheumatology, IMIBIC/Reina Sofia Hospital/University of Cordoba, Cordoba, Spain

Background: Rituximab (RTX) has been shown to be successful in the treatment of rheumatoid arthritis (RA), indicating that $B$ cells have an important role in this disease.

Objectives: The present study was undertaken to investigate the mechanisms of action of RTX on the immune and endothelial cells (EC) of the vascular system in the setting of RA.

Methods: Purified lymphocytes from five RA patients with high disease activity were treated with RTX $(1 \mathrm{ug} / \mathrm{mL})$ for 24 hours. Then, the depletion of B cells was assessed by flow cytometry, and the changes occurred in the inflammatory profile of T-lymphocytes was analysed by RT-PCR. In a second set of experiments, to evaluate the influence of B-cell depletion on the inflammatory/prothrombotic profile of cells belonging to the vascular system, supernatants from cultured lymphocytes of RA patients in the presence or in the absence of RTX were added to isolated monocytes from AR patients and to cultured endothelial cells. The response to RTX was then examined.

Results: As expected, RTX promoted a significant depletion of B-cells. In parallel, the inflammatory profile of $T$ lymphocytes from RA patients was downregulated, as shown by a significant drop of IL-1, IL-6, IL-17, IFN and TNF expression levels, thus suggesting that the anti-inflammatory effects of RTX might be related to B cell depletion. Supernatants from RTX-treated lymphocytes further abridged the prothrombotic profile of RA-monocytes, promoting a significant inhibition of TF, MCP-1, IL-8, IL-1 and VEGF-A gene expression. Moreover, endothelial cells, activated after treatment with supernatants from cultured RA-lymphocytes, showed reduced expression of cell-adhesion molecules (i.e. V-CAM, I-CAM, E-Selectin) and pro-thrombotic factors (i.e. TF, VEGF, IL-8) after treatment with supernatants from cultured RA-lymphocytes in the presence of RTX.

Conclusions: Overall, these results reveal that depletion of B-cells by RTX in RA influences the inflammatory profile of $\mathrm{T}$ lymphocytes, as well as their interaction with monocytes and ECs, thus modulating the inflammatory and prothrombotic shape of vascular cells in the setting of RA.

Acknowledgements: Supported by CTS-794, ISCIII (PI15/01333; RIER RD16/0012/0015)

Disclosure of Interest: None declared

DOI: 10.1136/annrheumdis-2017-eular.4916

\section{FRI0049 FC GAMMA RECEPTOR IV ENHANCES BONE EROSION IN EXPERIMENTAL ARTHRITIS BY PROMOTING INFLUX OF PMNS}

I. Di Ceglie ${ }^{1}$, G. Ascone ${ }^{1}$, M. van den Bosch ${ }^{1}$, J.S. Verbeek ${ }^{2}$, P. van der Kraan ${ }^{1}$, P. van Lent ${ }^{1}$. ${ }^{1}$ Experimental Rheumatology, Radboud University Medical Center, Nijmegen; ${ }^{2}$ Leiden University Medical Center, Leiden, Netherlands

Background: $\mathrm{Fc} \gamma \mathrm{Rs}$ are involved in regulation of synovial activation and bone destruction during immune complex (IC)-mediated arthritis. The balance between activating $\mathrm{Fc}_{\mathrm{c}} \mathrm{Rs}\left(\mathrm{Fc}_{\mathrm{c}} \mathrm{RI}, \mathrm{III}\right.$ and IV) and inhibiting $\mathrm{Fc}_{\mathrm{c}} \mathrm{RII}$ determines synovial activation. Here we investigated the particular role of activating Fc $\gamma$ RIV in bone erosion in IC-mediated antigen induced arthritis (AIA) by comparing $\mathrm{Fc} \gamma \mathrm{RI}, \mathrm{II}, \mathrm{III}, \mathrm{IV} \mathrm{V}^{-/-}$mice, $\mathrm{Fc} \gamma \mathrm{RI}, \mathrm{II}, \mathrm{III}{ }^{-/-}$mice and wild type controls (WT).

Objectives: To investigate the role of $\mathrm{Fc} \gamma \mathrm{RIV}$ in bone erosion during experimental arthritis.

Methods: AIA was induced by injection of mBSA into knee joints of mice previously immunized with mBSA/CFA. Joint inflammation, bone destruction, number of $\mathrm{TRAP}^{+}$osteoclasts and S100A8/A9 positive cells was determined using histology and immunohistochemistry. In vitro osteoclastogenesis was assessed using TRAP staining.

Results: Seven days after induction of AIA, we observed decreased inflammation and bone erosion in the knee joints of $F_{c} \gamma \mathrm{RI}_{1} \mathrm{II}, \mathrm{III}, \mathrm{IV}^{-/-}$mice compared to WT. The ability of bone marrow cells of $\mathrm{Fc} \gamma \mathrm{RI}, \mathrm{II}, \mathrm{III}, \mathrm{IV}^{-/-}$mice to differentiate into osteoclasts in vitro was comparable to the one of WT controls. Moreover, we observed comparable numbers of $\mathrm{TRAP}^{+}$osteoclasts on the bone surface of $\mathrm{Fc} \gamma \mathrm{RI} / \mathrm{II} / \mathrm{III} / \mathrm{IV}^{-/-}$and WT arthritic mice, suggesting that the observed decrease in bone erosion is mainly caused by a reduced osteoclast activity, rather than decreased osteoclast number. However, in contrast to $\mathrm{Fc} \gamma \mathrm{RI} / \mathrm{II} / \mathrm{III} / \mathrm{IV}^{-/}$, $\mathrm{AIA}$ induction in knee joints of $\mathrm{Fc} \gamma \mathrm{RI} / \mathrm{II} / \mathrm{III} \%$ resulted in increased bone erosion and inflammation compared to WT, highlighting the possible crucial role of Fc $\gamma \mathrm{RIV}$ in the pathology. Interestingly, the number of PMNs infiltrated in the knee joint of $\mathrm{FC} \gamma \mathrm{RI} / \mathrm{II} / \mathrm{III}^{-/-}$resulted increased, whereas it was decreased in the knee joints of $\mathrm{Fc} \gamma \mathrm{RI} / \mathrm{II} / \mathrm{III} / \mathrm{IV}^{-/-}$compared to their WT controls. This observation suggests that particularly Fc $\gamma$ RIV is involved in regulating influx of PMNs. PMNs are potent producers of alarmins S100A8/A9 which are described to promote osteoclast activity. In line the number of S100A8/A9 positive cells in synovium was increased in $\mathrm{Fc} \gamma \mathrm{RI} / \mathrm{II} / \mathrm{III}^{-/-}$while decreased in $\mathrm{Fc} \gamma \mathrm{RI} / \mathrm{II} / \mathrm{III} / \mathrm{IV}^{-/-}$, compared to their WT control. Conclusions: Fc $\gamma$ RIV promotes bone erosion in AIA by enhancing influx of PMNs within the synovium. PMNs are potent producers of S100A8/A9 which has been described to induce osteoclast activity.

Disclosure of Interest: None declared

DOI: 10.1136/annrheumdis-2017-eular.5386

\section{FRI0050 TYPE II COLLAGEN SECRETED FROM ARTICULAR CHONDROCYTES IS MAINLY DESTROYED BY CATHEPSIN S IN RA MICE}

J. Zhao, Q. Huang, H. Ren, M. Yang. Department of Rheumatology, Nanfang Hospital, Southern Medical University, Guangzhou, China

Background: Mast cells have long been recognized to increase strikingly in number in the synovial membrane of rheumatoid arthritis (RA), accounting for $5 \%$ of the surface synovial membrane cells. Type II collagen has the longest half-life in cartilage matrix. The main cells which might affect articular cartilage in RA are synovial fibroblasts, synovial macrophages and mast cells. The latter two could express cathepsin S.

Objectives: We aimed to find the cells which have the biggest influence on type II collagen secreted from articular chondrocytes and the possible mechanisms in RA mice.

Methods: Four types of cells from collagen-induced arthritis model-established C57BL/6 mice were primary cultured, including synovial fibroblasts, peritoneal 